\title{
Assessment of the process of urban transformation in Baghdad city form and function
}

\author{
Mazin Al-Saffar \\ School of Architecture. Manchester Metropolitan University. Manchester. UK \\ E-mail: mazinalsaffar75@yahoo.com
}

\begin{abstract}
During the 21st century, urban transformation of cities has been intensely affected by flows of socio-economic and technological processes. Through the centuries, such as all historical places in Mesopotamia, Baghdad has given an outstanding example of dramatic evolution. The city, which stands on the river Tigris, faced various transformation processes in the culture and physical environment due to social and political reasons. The transformation of Baghdad city is a very complicated process driven by various factors affecting the homogeneity of the old urban fabric. Reconfiguration and the production of new urban typologies within the heritage fabric were the most fundamental effects. The outcome was different spatial languages competing with each other. This transformation changed the relations and hierarchies among spaces, which allowed more flexibility and accessibility between private and public space. The main purpose of this study is to examine how Baghdad city emerged and to develop a comprehensive understanding of the history of urban transformation in the context of city change. To achieve this aim, this paper will utilize urban morphology to explain how Baghdad transformed from a geometric city (the Round City AD762 by Caliph Al-Mansur) to an organic form and then from a traditional city to the modern metropolis. It will seek to analyze the process of urban transformation in Baghdad and show different types of urban patterns. Moreover, this paper will try to illustrate how the new way of transportation represented by the car has affected the historic center and changed the structural system of Baghdad.
\end{abstract}

Keywords: Urban transformation, urban form, urban morphology.

\section{Introduction}

Bagdad is the capital and largest city in Iraq, its population approximately eight million, making it the second largest city in the Arab world after Cairo, Egypt. The modern city of Baghdad contains four main historic districts: Karkh, Kadhimiya, Adhamiya and Old Rusafa that represents the traditional centre of Baghdad. The complex growth and transformation in the historical places of Baghdad have produced various and partly conflicting urban systems. The opening of new wide streets was the first change in these traditional areas. The roads have penetrated and changed the traditional urban characteristic and form of Baghdad (Al-
Saffar, 2016). This paper will offer a review of the process of urban transformation in the context of city change through utilizing urban morphology to explain how Baghdad transformed from a geometric city to an organic form and then from a traditional city to the modern metropolis.

\section{Historical Background}

A set of factors played a substantial role to determine the locational choices of historic cities such as the availability of natural recourses, trade routes, and political considerations, and in some issues on the religious significance 


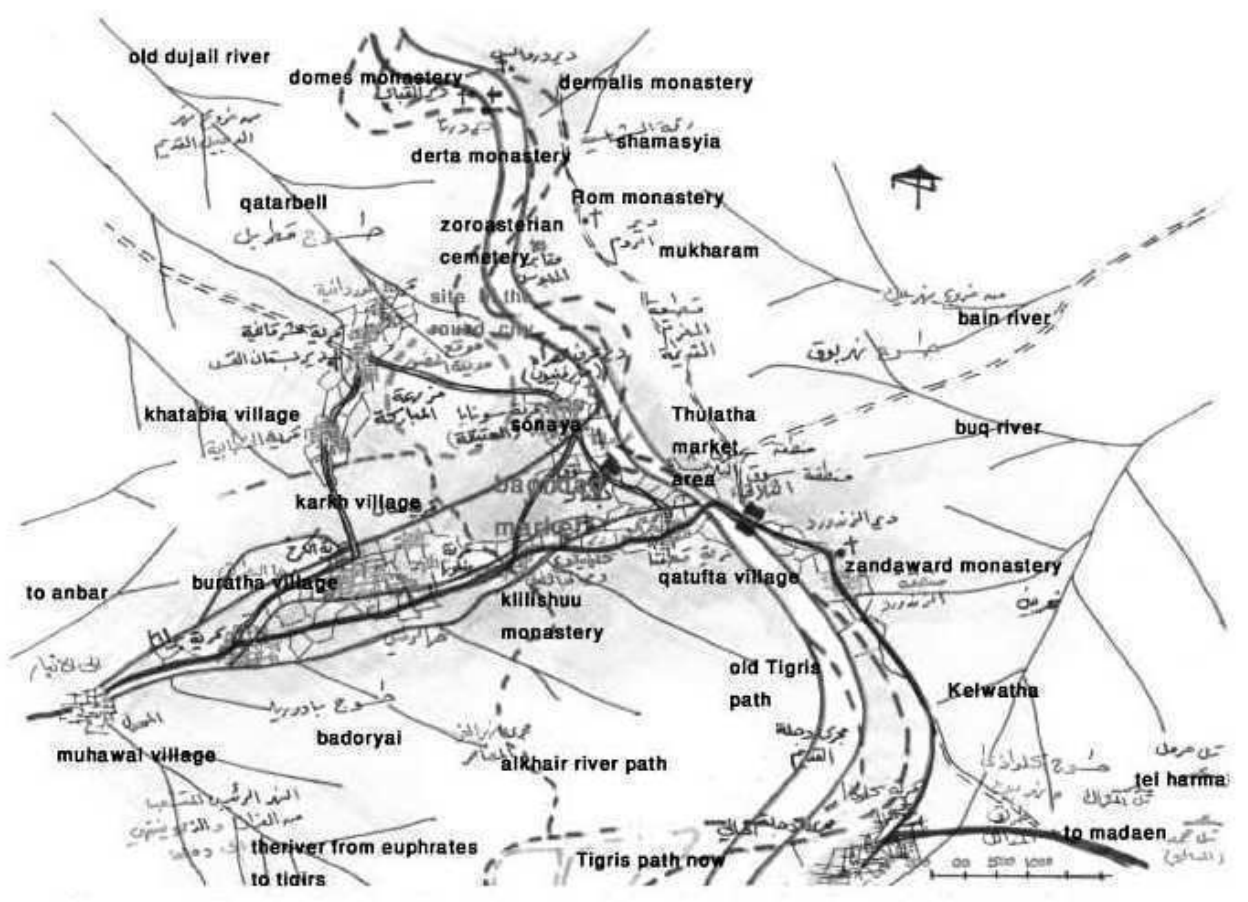

Figure 1.

The area of Baghdad in the first $\mathrm{AD}$ centuries before the building of the round city.

(Bianca, 2000:137). In the first century AD, most Mesopotamian cities grew on the bank of great rivers that are the source of prosperity to the country. Many villages and towns were connected by waterways and canals on both sides of the river Tigris. In the early 7 th century, there is mention in the historical writings of a market called Baghdad on the western bank of the river Tigris, due to the transportation of goods and the massive agricultural activity. This shows that Baghdad market was a connecting area between east and west and it was regional market before the coming of sea routes, probably as part of the famous Silk Road on the way for convoys between India, Persia, and Iraq (Figure 1) (Al-Silq, 2008).

\section{The emergence of the city (The City of Peace 762-809)}

Baghdad faced the biggest challenge in its history when it was chosen by Caliph AlMansur to be his capital city. Al-Mansur was the second caliph of the Abbasid Empire and he ruled the Islamic world beginning in $750 \mathrm{AD}$
(Marozzi, 2014:2). Al-Mansur started searching many areas that deserved to be the place for a great empire ruling almost half of the known world stretching from Morocco to Central Asia. After discussion with his assistants and meeting with a number of citizens, he decided that Baghdad was the most appropriate area. In $762 \mathrm{AD}, \mathrm{Al}$ Mubaraka (meaning the blessed) was chosen as the site of the round city (The City of Peace), with a palace and mosque in its centre. The City of Peace took four years for construction (762-766 AD). The city had four equidistant gates (Kufa Gate, Basra Gate, Sham Gate and Khorasan Gate) and two main radial streets surrounded by a deep moat and three walls, $17 \mathrm{~m}$ high the outer one, $30 \mathrm{~m}$ high the middle and the most significant with balconies and watchtowers, then the inner third wall which separated private houses and the governmental buildings. In the main centre, there were the two impressive buildings, the mosque and the Royal Palace of the golden door. The fundamental feature of the palace was a massive $40 \mathrm{~m}$ dome roofing the central two floors (Al-Silq, 2008). The mosque had a square shape, a square minaret, a pulpit, 
a mihrab, five courtyards and two rows of columns around the courtyard. This mosque was built similar to Masjad-al-Nabi in Medina (Berehinejad et al., 2014).

In the following decades, the city started to extend beyond its wall because of limited space and increased population. The outer four gates were joined with roads going to the nearer villages; Karkh village was the most important one, which grew to be an urban area that covered the whole area to the south of the city. The surrounding urban district became much more complex each village grew and had its own mosque, market and administrative buildings. The market became an essential part of the city that played a significant role to promote its prosperity. Soon after, a new urban settlement was built by Caliph Al Mehdi the son of Al Mansur on the eastern side of the Tigris. Al Rusafa mosque was the first monument built in this new district the palace was built later. Al Mehdi city was also surrounded by a moat and wall and was joined to the circular city by a bridge (Al-Hasani, 2012). As the city continued to grow, many urban district and palaces were built such as Al Kuld palace, Issa palace, and Al Qarar palace. The population of Baghdad was around one million, and the city became one of the most multicultural places on earth with different nationalities and religions living there, reaching its peak with the golden age of Harun Al Rasheed. (786-809 AD) (Marozzi, 2014:38).

The name of Baghdad dominated the whole capital due to the cultural facilities and policies at that time, while the name of the City of Peace started to disappear progressively. The city consists of two fundamental parts, Karkh on the western bank of the Tigris and Rusafa on the eastern bank. The architectural type of the city at that time can be found from the illustrations in the historical books, which described the architectural type of Al Hira city that had an open central courtyard surrounded by arcades and within them, the most important large space called the iwan. The domes were the other significant features of the Abbasid age covering the large spaces (Al-Silq, 2008).

\section{New Urban Center (809-946)}

After Al Rasheed's death in 809 AD, the struggle between Al Amin and Al Mamoon to be crown prince reached the point of warfare. Al Mamoon's army attacked the round city, destroying part of its walls, and many palaces, and killed Al Amin. The new Caliph decided to move to the Rusafa area and construct a new royal palace. Later several building and palaces were constructed around the royal palace, forming a new urban center on the eastern bank of the Tigris called Dar Al Khilafa (house of Caliphate) (Al-Silq, 2008). After the death of Al Mamoon in $833 \mathrm{AD}$, the new Caliph Al Mutasim moved the capital of the Abbasid Empire to Samara in 836 AD.

Later Abbasids returned from Samara in 892 $\mathrm{AD}$, and a new city center in Al Rusafa was constructed with a half-circular wall (Bianca, 2000:249). A market grew around the new urban center, Thulatha, and developed many urban districts, which became the historical center of Baghdad city. These districts have their own center containing the two main components the mosque and the market, and a variety of buildings, for instance, schools, libraries, public baths, hospitals and the most significant area composed of compact houses in narrow alleys. The new public center grew from three sides and was connected with the other side of the Tigris River by a bridge. This growth was organic in nature, which depended on the old existing paths and nodes. Paths distribution, the relationships between mass and space, compact fabric, a gradation of urban paths from public to private and the narrow alleys were the fundamental characteristics of the urban structure of the city (Al-Silq, 2008). The extension of the new urban center has led to the building of a new wall for more protection from the external power (Figure 2). This city wall and its structure remained until the end of the 19th century.

\section{The Dark Periods}

The history of Baghdad witnessed an eventful path of prosperity in times such as the Abbasid Empire when Baghdad had many 


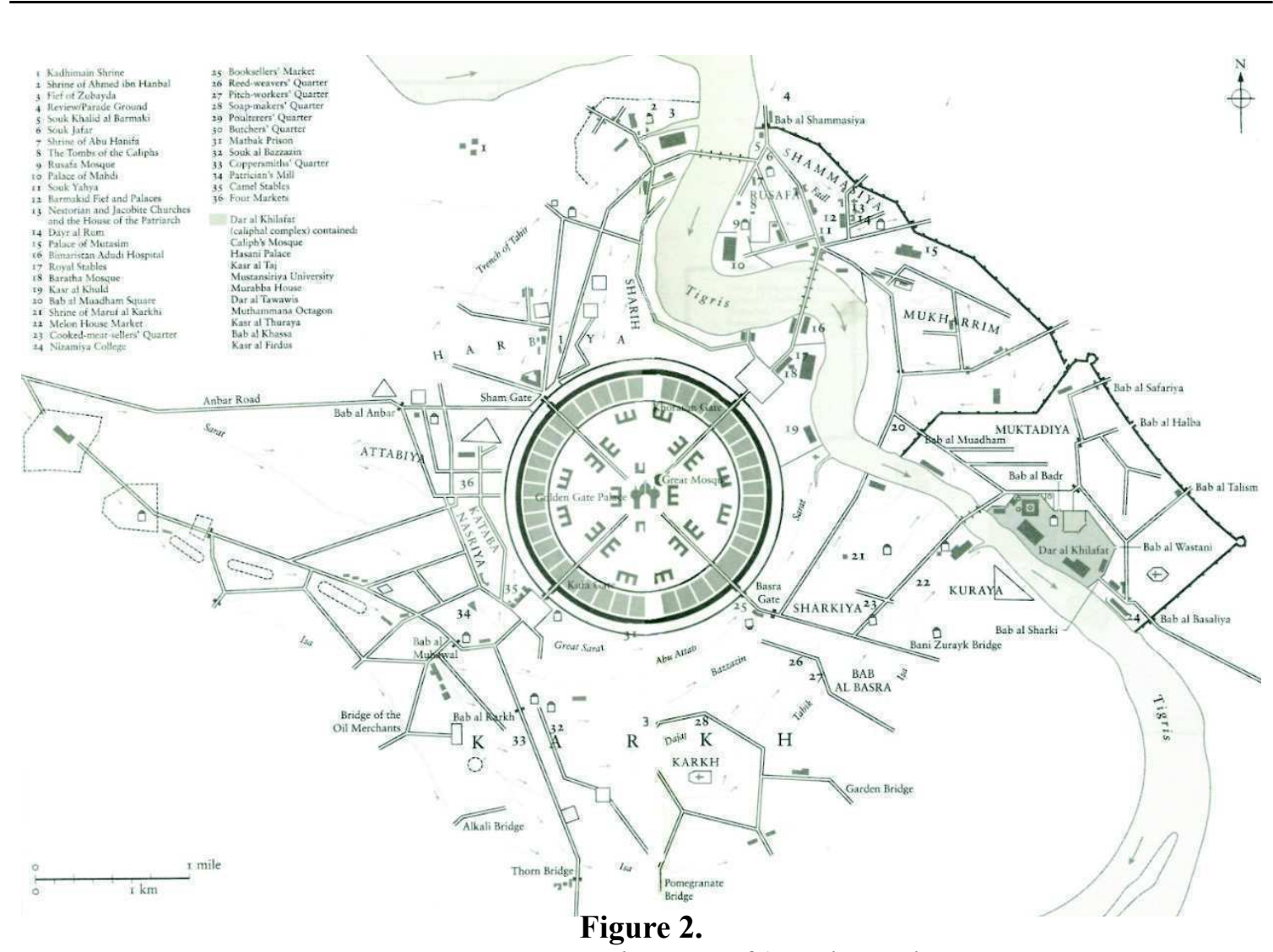

Baghdad morphology until the end of Abbasid Empire.

unique libraries. The House of Wisdom was an attraction point for the most significant thinkers, scientists, mathematicians and linguists of the world. However, Baghdad had also a difficult time of floods, epidemics, fires and foreign control. In 1258 was the darkest period when Mongols occupied and destroyed the round city. The great Khan of the Mongols, Mongke in 1255 put his brother Hulagu Khan in charge of an army whose goals were to destroy the Abbasid Empire. Hulagu's army, estimated at over 150,000 soldiers, entered and occupied the City of Peace on February 10th, 1258 and destroyed mosques, palaces, libraries, and hospitals within one week (Figure 3). They threw the books from Baghdad's libraries into the Tigris River, which was said to turn black with the ink from the books. More important than everything, the Mongols killed between 200,000 and 1,000,000 people in that week of destruction. They left Baghdad completely depopulated and uninhabitable (Marozzi, 2014:143).

Up to the 20th century the city has been occupied many times by different groups, for instance, the Buwaihids (946-1055), Seljuks
(1055-1152), Ilkhanid (1258-1338), Jalairids (1338-1411), Ottomans (1638-1917), the British (1917-1932) and the Americans (2003) have all left their marks in varying degrees and reduced Baghdad's status (JCP, 1984). Caliph Al Nasir and Caliph Al Mustansir tried in the early 13th century to bring some well-being back to Baghdad. They constructed important buildings such as Al Mustansiryia School, Al Nasiryia Palace (The Abbasid palace), the Tomb of Zumurid Khatun (Al Nasir's mother) and Al Khulafa mosque, which are still the oldest existing features of Baghdad. Al Khulafa mosque was built to be Dar Al Khilafa (House of the Caliphate), its minaret still exists but now beside a new mosque built in 1960 (AlSilq, 2008).

In the 17th century, a map shows Baghdad surrounded by a quadrilateral wall with four gates on the eastern bank of Tigris River while Karkh on the western bank was reduced to a linear area with small neighborhoods. Another map in the 18th century documented the city with its four gates, Kulwatha Gate or Eastern Gate, Muatham Gate, Wistani Gate and Talsam Gate, also it was indicated that there were 


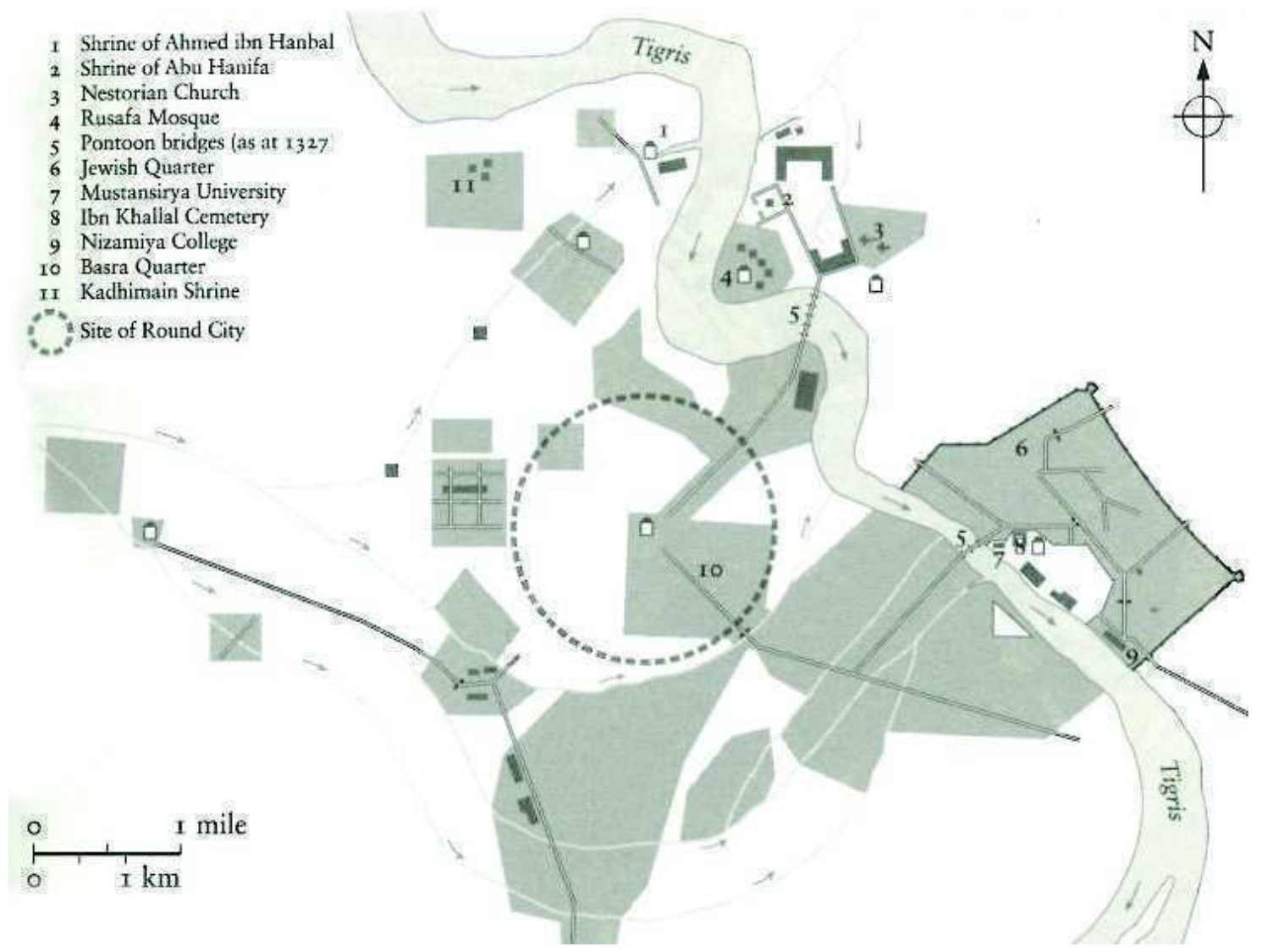

Figure 3.

Baghdad 1258-1534

22 Khans, several public baths, and 20 big mosques. The urban components were well organized and combined in the 19th century due to the geometrical form of the city. The street pattern of Baghdad was narrow and irregular, the houses were more suitable for the social and climatic characteristics of the city and fully integrated with their urban context. In the late 19th century, the Ottoman began to cut the first axis in Baghdad Rasheed Street and attempted to import Westernization into the urban evolution pattern (Al-Hasani, 2012) (Figure 4).

\section{New urban transformation (Baghdad in 20th century)}

Another change occurred in 1917 during WWI, after centuries of Ottoman control when the British Army entered Baghdad and once again it becomes a capital city looking to construct a new contemporary country, but under the British mandate. Baghdad witnessed a new change in the urban components and with the cultural structure in the beginning of the 20th century due to the political, economic and social situation. The opening of Rasheed Street in 1908 and then completed by the British was the first change in the traditional urban fabric. The street became the most significant feature and the center of business in Baghdad city for decades. The traditional style of buildings on Rasheed Street had a unique type, which gave the street an outstanding character.

New urban districts emerged outside the historical area in different directions in the 1930s, the new districts (Saadoon to the south, Waziryia to the north and Salihyia and Karadat Maryiam on the western bank of the river) were designed according to the western methods like gridiron planning and the garden city (Al-Silq, 2008), while the old urban fabric developed in two directions towards the Northwest and the Southeast. At the same time, the urban evolution programs neglected the urban heritage concerning renovation and preservation of the old traditional sites. Again 


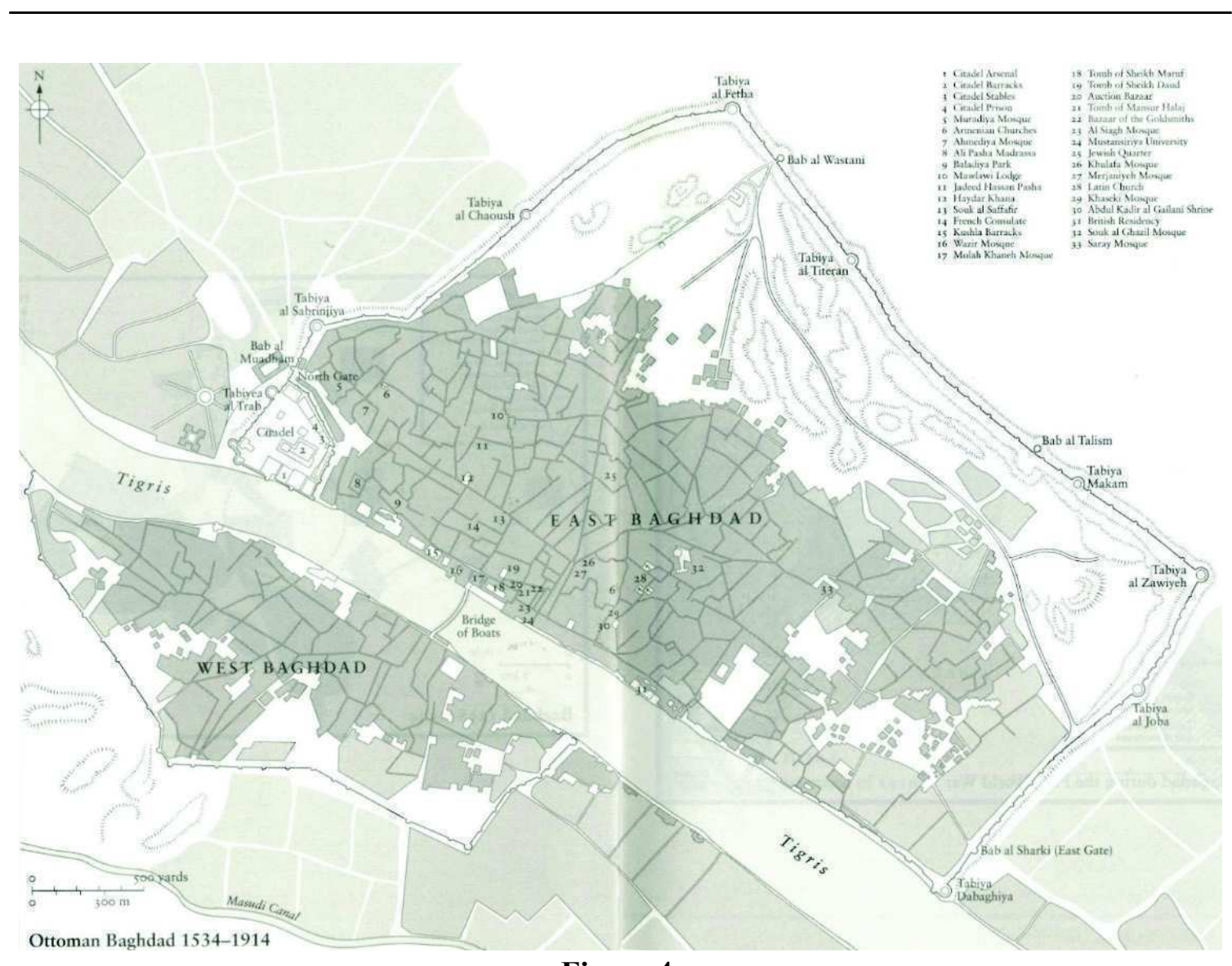

Figure 4.

Baghdad 1534-1914

three major roads (Kifah Street, Sheikh Omar Street and Khulafa Street) were penetrated into the historical fabric of Rusafa parallel to the Tigris River between World War One and Two (Al-Hasani, 2012), with a rate of demolition of about 32 hectares or $6 \%$ of the whole site of the old city (JCP, 1984) (Figure 5).

After the massive increase in economic resources in the 1950s, the establishment of the Higher Council for Reconstruction determined the modern planning strategy for the city (AlHasani, 2012). Furthermore, and huge projects in Baghdad were implemented such as electric power stations, oil refineries, large factories, and dams, which were essential projects to protect the Mesopotamian valley from the risk of floods. These circumstances led to the invitation of many famous architects in the world to design projects and create unique concepts for Baghdad city. They tried in their designs to combine different ideas: Wright by designing the Opera House of Baghdad and the master plan for greater Baghdad, and Gropius in his design of the University of Baghdad created a sophisticated system of masses and spaces inspired from the courtyards in the old city. In addition, the amazing design of Baghdad Gymnasium building by Le Corbusier, the Ministry of Planning by Ponti and the Art Gallery by Aalto were also planned (Al-Silq, 2008).

The Iraqi Government between 1956 and 1984 appointed various international architects and planners to prepare master plans due to the rapid extension in Baghdad city. P.W. Macfarlane was the first one who proposed in 1956 eight sectors each one with a population of about 18000 and a road system joining the historic urban area in Baghdad with new river bridges and the outlined districts. In 1958, modern urban planning of five sectors of Baghdad was submitted by Doxiadis. He suggested a rectangular district along the north-west and the south-east axis of the river. Doxiadis's master plan aimed to achieve a more comprehensive framework for modernization (Pyla, 2008). The third master plan by Polservice for Baghdad city in 1970 


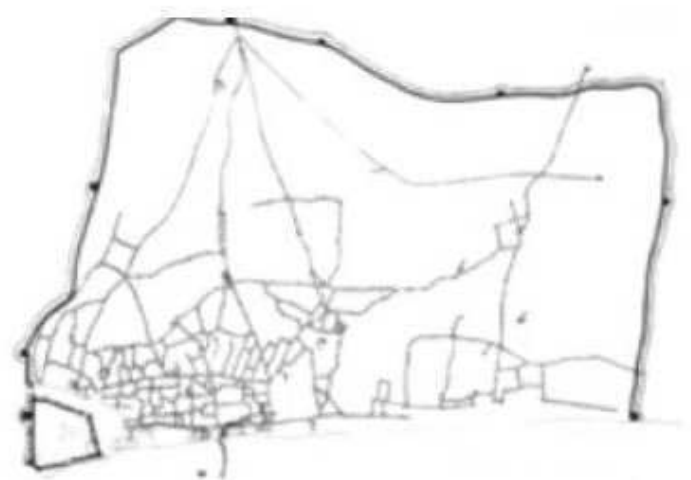

Old Rusafa

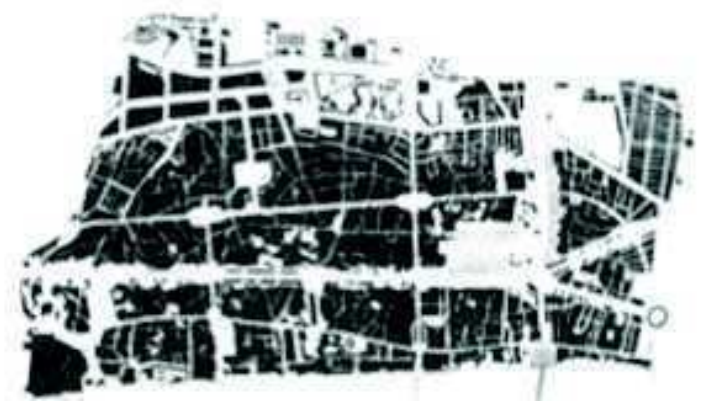

Reconstruction Boom: 1970

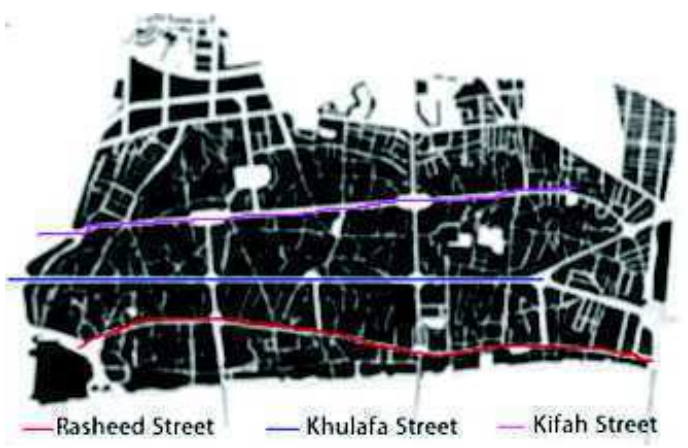

Westernization: 1800-1960

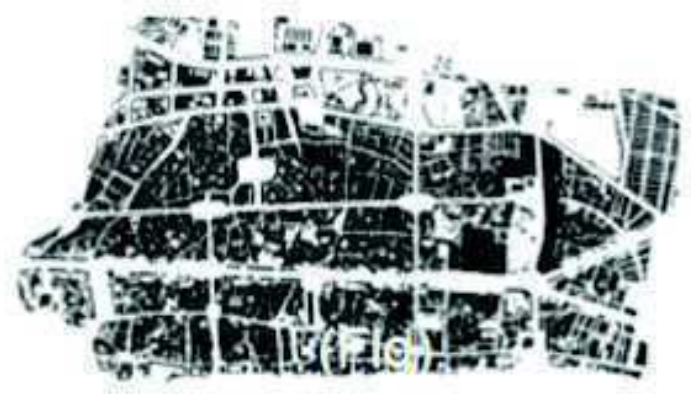

Urban Change: 1983

Figure 5.

Urban Transformation in Historic Part of Baghdad (Old Rusafa)

determined the administrative boundaries and the development strategies until 2000. Polservice recommended preserving as many as possible of the traditional sites and urban fabric of the historic quarters. The last comprehensive master plan for Baghdad was submitted by JCCF in 1987.

One of the significant comprehensive urban conservation master plan for Old Rusafa was submitted by JCP (Japan planners, architects, and consulting engineering) in 1984. Urban conservation and redevelopment of the traditional core were the main aims of this scheme. The importance of this plan is not envisaged as merely a passive protection of the existing historic centre. In addition to proposing the conservation, restoration or rehabilitation of significant portions of the historic centre, the structure plan and urban design schemes aim for an active development of the historic fabric. This includes the retrieval of many fundamental parts which, if realized, would greatly improve the image of Old Rusafa (JCP, 1984).

\section{Assessment of the process of urban transformation in Baghdad city form and function.}

In Figure 6, I have analyzed the process of urban transformation in Baghdad and showed a different type of urban pattern. The city began with a circular geometric form (The Round City) from 767 to $912 \mathrm{AD}$ and then transformed to more organic pattern until the end of the 19th century. This transformation changed the relations and hierarchies among spaces, which allowed more flexibility and accessibility between private and public space. Baghdad has witnessed another transformation in the 20th century due to the urban growth, political issues and economic evolution. The new geometrical areas with new wide streets have increased the pressure on the historic part of the city physically, economically and socially. Since the last transformation the relation between private and public in the new districts has changed, privacy has started to disappear and converted to publicity, and 


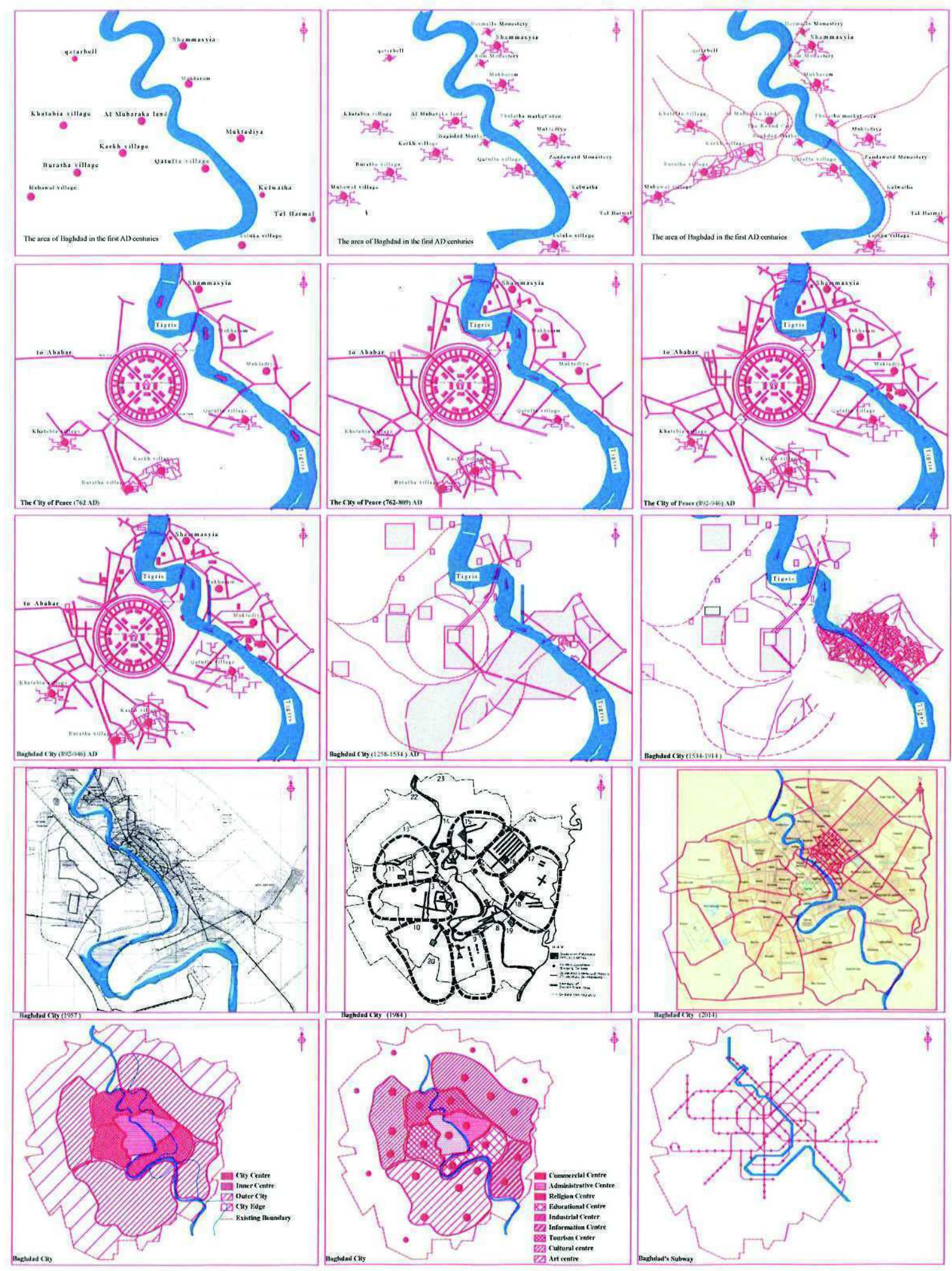

Figure 6.

The Urban growth and Transformation in Baghdad city from the first AD to 2017 
public spaces are still looking for their identity (Al-Hasani, 2012).

The analysis and illustration of the urban growth, morphology and the transformation of Baghdad city in Figure 7 started from the first century $\mathrm{AD}$ when the area of Baghdad was still small cells and then developed to be villages that have organic patterns connected to each other through natural paths (waterways, canals, and routes). To use ideas from Batty this analysis shows that Baghdad started with stochastic growth from the bottom up based on developing one of these cells to be the main point for attracting other cells such as Karkh village. For example Batty has stated that although "the city has grown in some direction instead of others is largely due to a combination of physical and accidental historical factors, it does not imply any differences in the way growth has occurred from one time period to the next" (Batty et al., 2006). Later Baghdad witnessed another type of growth, top down, when one of it settlements was chosen to be the place of the Abbasid Empire and a comprehensive master plan (the round city plan) was prepared for it. This type of growth represents a different method for thinking at that time and a new urban form and pattern was produced due to that. This shows according to Batty's analysis that systems are resilient and have the ability to represent different forms of transformations reliant on the processes that generate them.

The limited space and fixed boundaries of the new geometric pattern played a fundamental role to promote the organic form, which had the ability and flexibility to extend and evolve. In addition, we will find that the geometric pattern created new nodes and urban networks that produced new processes for developing urban transformation and led to a growing complex structure in Baghdad city. Each one from these networks had their own unique urban components such as mosque, palace, market and administrative buildings and showed strong levels of connectivity that indicate the fact that Baghdad city had reached a level of self-organization in the golden age of Harun Al Rasheed (786-809 AD).

Baghdad had only an organic pattern after the destruction of the round city in 1258 by the Mongols and that pattern remained until the 20th century when a new essential change in the political, economic and social situation pushed such systems into another regime. The new way of transportation represented by the car also invaded the traditional fabric and changed the structural system of Baghdad. Due to that, new urban systems and forms emerged outside the historical area in different directions and three major roads were penetrated into the historical fabric of Rusafa parallel to the Tigris River. Nowadays Baghdad has a complex system and varied urban forms.

I have tried also through my analysis in Figure 6 to show how such a system has the ability to grow and change in different forms affected by technological innovations. These new forms or networks are defined by their functions and connections to each other through various ways such as invisible smart electronic networks, smart transport systems, and smart central control systems. However, it still needs to be discovered who will be responsible for managing these new systems, what type of processes and morphology they will follow to build themselves. Furthermore, how these systems will develop and protect the traditional fabric in Baghdad and became an example for other historic cities, most importantly "what modern information technologies might do to the future city during the next 100 years" (Batty et al., 2006), will be the subject of more extensive research.

\section{Conclusion}

This research has endeavored to realize the spatial features, structure and identity of Baghdad through examining the process of its urban transformation and growth, and by analyzing its physical structures at different stages and periods. Ahmadi et al., (2012) assert, "New cities form rapidly and usually follow many unconnected concepts that cause confusion in urban spaces, while historical cities were formed gradually according to accepted patterns and rules. Many non-local agents influence the form of new cities, while the form of traditional urban spaces depends on the morphology of the site, the historical 
background and the culture of the local people" (Ahmadi et al., 2012). Thus, urban designers, policy-makers, architects and governments should consider devising regeneration solutions and endeavors dealing with historic cities, aiming to integrate traditional principles with contemporary needs and provide a new vision for rethinking the way cities are designed, built, and managed. Moreover, we should seek to find new methods of regeneration that might help to find the positive and negative aspects that can serve as a platform to resolve the conflicting values of traditional urban form and contemporary design models.

\section{References}

Ahmadi, V., Chi-Ani, A.I., Farkisch, H., and Surat, M. (2012) MORPHOLOGICAL STUDY OF URBAN HIERARCHY IN BOSHROOYEH CITY OF IRAN. International Journal of Architectural Research, 6(3), 56.

Al-Hasani, M. (2012) Urban space transformation in old city of Baghdad-integration and management. Megaron Architecture, 7(3), 79.

Al-Saffar, M. (2016) Toward an Integrated Sustainable Urban Design Framework in the Historic Center of Baghdad. The International Journal of Environmental Sustainability, 13(1), 31-52.

Al-Silq, G. (2008) Baghdad - Image and Memories. DC PAPERS : Revista de Crítica y Teoría de la Arquitectura(1139-5559), 4665.

Batty, M., Barros, J., and Júnior, S.A. (2006) Cities: continuity, transformation and emergence. In E. Garnsey, and J. McGlade, Eds. Complexity and Co-Evolution Continuity and Change in Socio-Economic Systems, p. 61-75. Edward Elgar Publishers, UK.

Berehinejad, M., Chelongar, M., and Jamalli, M. (2014) Comparison of Baghdad and Cordoba Urban Planning. World of Sciences Journal 2(4), 48-55.

Bianca, S. (2000) Urban form in the Arab world: past and present. (Thames \& Hudson, London).
JCP. (1984) Study on Conservation and Redevelopment of Historical Center of Baghdad City. Republic of Iraq, Amanat Al Assima.

Marozzi, J. (2014) Baghdad : city of peace, city of blood. (Penguin Group, London).

Pyla, P. (2008) Back to the Future: Doxiadis's Plans for Baghdad. Journal of Planning History, 7(3), 4-19. 